\title{
The characteristics of, and motivations for, Indigenous student mobility: Examples from urban and regional Queensland, Australia
}

Fiona Navin

Angela Hill

Tanya Doyle

School of Education, James Cook University, Townsville, 4811

Queensland

Australia

angela.hill@jcu.edu.au

Telephone: +61 747816351

Fax: +61 747816145

Keywords: Indigenous mobility; spatial patterns; reasons for mobility; localised policy responses

This is the Accepted Version of a paper published in a special edition of the journal International Journal of Educational Research: Navin, F., Hill, A., \& Doyle, T. (2012). The characteristics of, and motivations for, Indigenous student mobility: Examples from urban and regional Queensland, Australia. International Journal of Educational Research. 


\title{
The characteristics of, and motivations for, Indigenous student mobility: Examples from urban and regional Queensland, Australia
}

\begin{abstract}
Using the notion that research should 'enlighten’ policy responses, this paper considers the complex locational factors that affect and underlie patterns of Indigenous student mobility in Queensland, Australia. The paper presents data, captured through an action research project, to explore mobility 'in and through' two environments. In so doing, it argues that the complexity of local sites and experiences, and distinct 'push-pull' factors in remote, regional and urban settings, are critical considerations when developing a 'policy package' in response to Indigenous student mobility. In this regard, more effective use and analysis of administrative data are required.
\end{abstract}

\section{Introduction}

The literature describing the characteristics of, and motivations for, student mobility can be conceptualised into three broad categories. One category is mobility commonly associated with the positive 'flows' of globalisation where the children of upwardly mobile professionals move to engage with increasingly borderless employment options. The scale of this mobility is not well documented, but motivations are limited to those of substantive privilege, increasing ‘horizons of action’ and considerable agency (Robertson \& Dale, 2011). A second category of student mobility concerns children from mobile cultures or communities such as Gypsy Travellers, Show and Fairground peoples and seasonal workers (Danaher, Moriarty, \& Danaher, 2009). A third category of student mobility relates to individual movement resulting from dislocation and marginalisation - in particular refugees.

In England, a number of large-scale projects have been undertaken to determine the patterns of mobility within the third category of student mobility, with a focus on refugee children (see Department for Education and Skills, 2003a; Dobson, Henthorne, \& Lynas, 2000; Office for Standards in Education, 2002). This research has led the Department for Education and

This is the Accepted Version of a paper published in a special edition of the journal International Journal of Educational Research: Navin, F., Hill, A., \& Doyle, T. (2012). The characteristics of, and motivations for, Indigenous student mobility: Examples from urban and regional Queensland, Australia. International Journal of Educational Research 
Skills (2003b) to produce a comprehensive guide to working in highly mobile (although not always disadvantaged) contexts.

In the United States, Rumberger's (2003) research also identified that the highest levels of student mobility were enacted within "large, predominately minority, urban school districts" (p.7). More recent US research (Beesley et al.,2010) calls for further research into student mobility, noting that mobility rates are significantly higher where schools are located on or near American Indian reservations. In general terms this body of research indicates that "high mobility schools tend to have higher proportions of disadvantaged children" (Dobson et al., 2000, p.81).

Coupled with emerging research from Australia (Prout, 2008, 2009; Prout \& Howitt, 2009) noting the movement of Indigenous Australians, intersections of race and class are increasingly in focus in recent discussions of student mobility. Prout (2008, p. 8) contends that there is a significant lack of research "regarding urban Indigenous temporary mobility trends ... the characteristics of mobility and movers in urban areas are largely unknown and obscured”. The reasons for mobility in contexts of disadvantage are much less understood than those of mobile 'groups' such as Gypsy Travellers, but as Prout (2008) notes, the reasons relate to both 'push' and 'pull' factors. 'Pull' factors might, for example, include the need to access health services in a larger urban centre, while 'push' factors might relate to, for example, overcrowding in housing.

The identification of - and indeed a greater understanding of - the various reasons for mobility within and across school sites in contexts of urban disadvantage was the key objective of the study reported on in this paper. It analyses empirical data collected within six schools: three in each of two separate geographical locations of Queensland, Australia. Each of these schools recently began receiving additional government funding to support improvements in the literacy and numeracy outcomes of highly mobile Indigenous students as part of a broader national policy turn towards programs of social inclusion. For educators working with Aboriginal and Torres Strait Islander students in Australia, the policy turn centred around 'Closing the Gap': a major social inclusion initiative that aims to halve the gap in Year 3 reading and numeracy by 2012 and to 'close the gap' in student attendance by 2013 and in Year 12 retention by 2013 (Queensland Government, 2011). As Smyth (2010) warns, however, a key missing link in the Australian government's approach to social 
inclusion is the lack of any genuine attempt to understand the complexities of disadvantage. Instead, there is an overemphasis on the 'tight and narrow' frames of 'high stakes' accountability testing (Lingard, 2010). Our aim in this paper therefore, is to shed light on some of the complex intersections between Indigenous student mobility and schooling in the context of urban disadvantage.

\section{Methodology}

The data for this study was drawn from six schools in two locations in Queensland, who were engaged in a collaborative research project involving state primary schools experiencing high levels of socio-economic disadvantage. The research operated within a critical participatory action research framework. Critical participatory action research encourages critically reflective practice and considers the connections between education and wider structures of cultural, political and economic power to address problems (Beyer \& Apple, 1998). This project sought to investigate the local challenges of globalisation in a 'bottom up approach' (Appadurai, 2000) combining the principles of action and research in a co-generative research team comprising school leaders, teachers, Indigenous Education Workers, and university researchers in each cluster of schools. Throughout the paper, the schools and their locations are referred to by alias. The locations, Cityedge and Greenville, are outlined in detail later in the paper but represent contrasting enrolment proportions of Indigenous students - the three Cityedge schools range between $8 \%$ and $11 \%$ while the three Greenville schools range between $58 \%$ and $65 \%$.

As was the case for many of the studies reported on in this special issue (see Doyle \& Prout, this issue; Lynch, Hill, \& Dalley-Trim, this issue), a resource-intensive micro level analysis of movement in and out of schools was used to measure and map student mobility. The Joiners Plus Leavers (JPL) measure (Dobson et al., 2000) captures every student movement in and out of schools across the year. In addition, length of stay for each school leaver was recorded and detailed information about schooling history, previous schools and motivations for movement was collated. The enrolment process at each of the six schools was assisted by a Mobility Support Teacher, who, in collaboration with the Indigenous Education Worker in the school, collected a range of information from the enrolling family and the previous school/s that the student/s had attended. 
Data collection tools were developed in collaboration with each school. Those capturing and entering the data - Mobility Support Teachers, Indigenous Education Workers and administration officers - were trained how to enter and extract data from two separate databases - one that already existed as part of the school system and the other developed as part of the project. It was important, then, to engage with these staff members and for them to see the power of accurate data collection. To this end, the research team ensured that the staff were included as part of the action research team and followed up any gaps in data collection or extraction.

Throughout the analysis, data are presented disaggregated into four separate cultural backgrounds - that is, Aboriginal, Torres Strait Islander, Aboriginal and Torres Strait Islander and non-Indigenous. Such disaggregation is particularly relevant in Queensland where the Indigenous population is particularly diverse and it is critical to be attentive to the "limitations of the suitability and applicability of research and policy that egregiously assumes an undifferentiated whole when considering Indigenous people” (Mellor \& Corrigan, 2004, p. 3). Some data sets accessed did not enable separation into the aforementioned identities. In these instances Indigenous and non-Indigenous are used.

\section{Contrasting data sets}

The intensive and rigorous micro level analysis involved in the collection of this data was in contrast to the measurements system currently utilised by the Queensland Education Department. The Department's School Enrolment Continuity measure considers and names the proportion of students that left a school, were new at a school, or were continuing students at a school. Data collections are undertaken in February, July and November of each school year, however points of comparison are only drawn between two collection dates. For instance, between February and July, July and November, or February and November. In contrast, the Joiners Plus Leavers (JPL) measure captures every student movement or transaction in and out of schools across the year. Data is extracted from a Student Management System to map every new enrolment and every exiting student across the year. In Queensland, when a student enrols in a school, a Transfer Note is sent from the enrolling school to the previous school requesting the student's schooling history. A student is listed as 'enrolled' at a school until a Transfer Note is received, regardless of any period of absence. 
Table 1 presents a comparison of the two aforementioned measures across the six school sites in 2009, disaggregated by Indigenous status. The data presented here indicates that the School Enrolment Continuity measure captured less than $75 \%$ of the enrolling students who were captured by the JPL measure.

Table 1: Student enrolment over 2009 as measured by JPL and School Enrolment Continuity measures

\begin{tabular}{|c|c|c|c|c|c|c|}
\hline \multirow[t]{2}{*}{ School } & \multicolumn{3}{|c|}{$\begin{array}{c}2009 \text { JPL } \\
\text { Joiners }\end{array}$} & \multicolumn{3}{|c|}{$\begin{array}{c}2009 \text { School Enrolment Continuity } \\
\text { New at school }\end{array}$} \\
\hline & Indigenous & Non-Indigenous & Total & Indigenous & Non-Indigenous & Total \\
\hline Cityedge East SS & 15 & 128 & 143 & 10 & 98 & 108 \\
\hline Cityedge South SS & 14 & 150 & 164 & 7 & 112 & 119 \\
\hline Cityedge North SS & 10 & 62 & 72 & 5 & 49 & 54 \\
\hline Greenville West SS & 133 & 53 & 186 & 91 & 44 & 135 \\
\hline Greenville East SS & 36 & 24 & 60 & 20 & 13 & 33 \\
\hline Greenville South SS & 89 & 66 & 155 & 59 & 58 & 117 \\
\hline
\end{tabular}

Further analysis of Table 1 indicates that, while Cityedge schools have a low proportion of Indigenous student joiners, the Department's measure of enrolment underestimates the number of Indigenous students who have joined the schools by as much as $50 \%$. Within the Greenville schools, the underestimation is approximately 40\%. An explanation for this underestimation of movement relates to the patterns of enrolment we have mapped for many Indigenous students - that is, some Indigenous students will enrol at one school site, leave for a period and then return to the same site. This may occur several times during the year, possibly coinciding within the census collection points of the School Enrolment Continuity measure. For example, in 2009 one student enrolled on January 27, exited on March 24, reenrolled August 19, and was still enrolled in November. When matching enrolments in February and enrolments in November, this student would appear as a continuous enrolment in the School Enrolment Continuity measure.

Table 2 presents a comparison of 'leavers' as measured by the JPL measure compared to those who have 'left the school' as captured by the School Enrolment Continuity measure. Again this measure underestimates the number of students, and particularly Indigenous students leaving a school site. Patterns of repeat enrolment at the same school and the length of stay explain these differences. It is important to note that while the Joiners Plus Leavers (JPL) measure captures much more movement of Indigenous students, there are still those 
mobile students who may be 'invisible' to this micro analysis. For example, a student may be absent for a short period travelling to another location. The student does not formally exit the school, but re-enters the school after the absence. While a teacher may hear of this movement, it is not captured in the data collection process as there is no formal exit procedure.

Table 2: Student departures as measured by JPL and School Enrolment Continuity measures

\begin{tabular}{lcccccc}
\hline \multirow{2}{*}{ School } & \multicolumn{3}{c}{$\begin{array}{c}\text { 2009 JPL } \\
\text { Leavers }\end{array}$} & \multicolumn{3}{c}{$\begin{array}{c}\text { 2009 School Enrolment Continuity } \\
\text { Left the School }\end{array}$} \\
\cline { 2 - 7 } & Indigenous & Non-Indigenous & Total & Indigenous & Non-Indigenous & Total \\
\hline Cityedge East SS & 19 & 109 & 128 & 5 & 79 & 84 \\
Cityedge South SS & 23 & 116 & 139 & 16 & 82 & 98 \\
Cityedge North SS & 12 & 58 & 70 & 6 & 39 & 45 \\
Greenville West SS & 107 & 28 & 135 & 62 & 24 & 86 \\
Greenville East SS & 76 & 33 & 109 & 47 & 16 & 63 \\
Greenville South SS & 70 & 39 & 109 & 46 & 28 & 74 \\
\hline
\end{tabular}

\section{Greenville community profile}

Sarra (2008) emphasises the need to develop meaningful understandings of how historical and sociological processes impact on contemporary settings. Indeed, a complex history of invasion, missions, forced dislocation and relocation paints a very complex backdrop for the Greenville area. At least six missions were established within a 300km radius of Greenville, with many different Indigenous groups represented in each (State Library of Queensland, 2011). Records of a mission near Greenville show that people had been removed from locations as far away as Brisbane (approximately $1400 \mathrm{~km}$ south) and Cloncurry (approximately $1000 \mathrm{~km}$ west) (State Library of Queensland, 2011). While missions have now been abolished, many communities have been established on or near the sites of missions due to historical ties to the area.

The Greenville schools then, are located within a community characterised by historical dislocation and, as evidenced by a range of social statistics, there is multilevel disadvantage in a regional centre of North Queensland. The community has been "put at disadvantage”" (Smyth, 2010, p. 124) by decades of dislocation and relocation, with many of the Indigenous families having historical and cultural connections to communities in the northern tip of Australia - Cape York - as well as the islands of the Torres Strait. A range of socio- 
demographic data pertaining to the Greenville community, coupled with a history of oppression, explain many of the patterns of mobility in the area.

The overall population of the Greenville community, for example, is noted as highly mobile. In 2006, 25.3\% of the population aged 5 and over lived at a different address one year ago, and 53.4\% lived at a different address five years ago (ABS, 2006). These population mobility rates are significantly higher than the recorded national averages. A total of $15.1 \%$ of the population identify as Indigenous (6.9\% Aboriginal, 5.7\% Torres Strait Islander and 2.4\% both Aboriginal and Torres Strait Islander) and it is noted that the Indigenous population is quite young (36.4\% aged 14 years or younger) (OESR, 2008). Of the Indigenous households in the Greenville community, 35.6\% were one-parent households, compared to $12.2 \%$ of nonIndigenous households (OESR, 2008). So, too, Indigenous households were more likely to be housing multiple families and be overcrowded $-25.6 \%$ compared to $4.3 \%$ of other households (OESR, 2008). As family dynamics change, housing circumstances may also change.

Housing ownership in the Greenville community is lower than the national average (32.6\%) for both Indigenous (5.0\%) and non-Indigenous (21.5\%) households (OESR, 2008). A rented dwelling is the most common type of housing tenure - $75.9 \%$ of Indigenous households and $50.6 \%$ of non-Indigenous households (OESR, 2008). Almost one third (27.8\%) of dependent children in Indigenous couple families, had both persons of the couple unemployed or not in the labour force (OESR, 2008). This is compared with 9.2\% for dependent children in nonIndigenous couple families (OESR, 2008). Given these measures of financial disadvantage, it is likely that an increase in rental price may force housing relocation.

With regard to measurements of socio-economic disadvantage, the schools are located in local government areas that constitute the most disadvantaged communities measurable within Australia - with two schools located in an area with the lowest possible decile of 1 , while the third is in the second lowest decile (ABS, 2006).

Thus, the history of dislocation, and the ongoing connections to a wide range of communities, coupled with low access to stable housing and income, creates conditions that are more likely to contribute to mobility. 


\subsection{Profile of schools in the Greenville community}

Each of the case study schools is located in established residential areas and the student population varied at each school. In 2010, the enrolled student population calculated at the February census date ranged from 249 at Greenville East to 544 at Greenville West. The student population was drawn, in part, from the surrounding suburbs that are characterised by a density of public housing, with some areas having the highest density of such housing in Queensland.

The Indigenous population at each of the schools ranged between $58 \%$ and $65 \%$. Many of these students speak English as a second, third or fourth language. Additionally, the schools serve students who identify as Papua New Guinean or Pacific Islander and, during the period of this study, the schools experienced an increase in the number of students who were refugees from African countries including Uganda, Tanzania, Rwanda and the Democratic Republic of Congo. Students from Nepal were also an increasing population within the school. These refugees are encouraged to relocate to regional Australia as part of a specific government policy objective "to support regional development and help supply the skill needs of regional employers” (Australian Government. Department of Immigration \& Citizenship, 2011).

Within Australia, schools are given an Index of Community Socio-Educational Advantage (ICSEA). The average ICSEA value is 1000, the ICSEA values of the three schools in this region represent significant disadvantage, ranging from 716 to 759 . The distribution of students also showed that $68-94 \%$ of students at the three schools were located within the bottom half of disadvantage. In summary then, the schools in the Greenville community are located in areas where there is a concentration of disadvantage: where there exist "multiple, interacting barriers to inclusion” (Smyth, 2008, p. 5).

\subsection{Student mobility in the Greenville region}

In the Greenville schools, data collected over the course of 2010 indicates that a total of 289 students enrolled or joined the three schools and 244 students left. The numbers of students joining and leaving the schools are disaggregated by cultural background as outlined in Table 3. 
Table 3: Indigenous status of 2010 Joiners and Leavers in the Greenville Cluster

\begin{tabular}{lcc}
\hline Indigenous status & Joiners & Leavers \\
\hline Aboriginal & 83 & 73 \\
Torres Strait Islander & 76 & 48 \\
Aboriginal and Torres Strait Islander & 59 & 55 \\
Non-Indigenous & 71 & 68 \\
\hline
\end{tabular}

It is important to note that the joining and leaving students may be two separate cohorts. For example, it is not necessarily the case that of the 83 Aboriginal students that joined, 73 of them later left the school, although for some students this pattern of movement is a reality. Using the Joiners plus Leavers (JPL) formula, each of the schools has a mobility rate of 50\% or higher for 2010 - Greenville East 57.2\%, Greenville West 50.0\% and Greenville South $53.7 \%$. When benchmarked against international studies, the mobility measured across all schools exceeds the 'very high' category. Our analysis disaggregated the mobility rates for Indigenous and non-Indigenous students. An analysis of Indigenous student movement shows that levels of mobility for this cohort are exceptionally high and Indigenous students are over-represented in the mobile cohort - Greenville East 67.4\%, Greenville West 54.7\% and Greenville South 66.8\%. It is of note, however, that levels of non-Indigenous mobility for this region are still considered ‘high’ to ‘very high’ - Greenville East 38.5\%, Greenville West 40.7\% and Greenville South 33.8\%.

Through close examination of the school data sets, we measured the length of stay for each student who left the school during 2010. The length of stay is calculated from a student's enrolment date to departure date, recorded as the date that a Transfer Note is received. Staff in the Greenville schools note that there is often a significant gap between the last day of attendance and receipt of a Transfer Note. So, while this length of stay data provides useful information to schools for developing policy packages in response to mobility, further research is required to explore the 'gap' between school movements.

As described in Table 4, 72\% (176) of students who left the school during 2010 were Indigenous. Fifty-two Indigenous students stayed less than three months or one school term in the one school location. A further 30 Indigenous students stayed less than six months or two terms in the one school location. Therefore, almost half (47\%) of enrolling Indigenous students stayed at the one school site for, at most, half of the school year. With some research 
noting links between mobility and early school engagement and achievement (Mantzicopoulos \& Knutson, 2000) it is also significant that 83 Indigenous students (47\%) who left the school were in Years 1-3 of schooling.

Table 4: Length of Stay for leavers in the Greenville Cluster 2010 (total number of leavers = 244)

\begin{tabular}{|c|c|c|c|c|c|c|c|c|c|}
\hline $\begin{array}{l}\text { Indigenous } \\
\text { Status }\end{array}$ & Cohort & $\begin{array}{c}\text { 0-3 } \\
\text { months }\end{array}$ & $\begin{array}{c}\text { 3-6 } \\
\text { months }\end{array}$ & $\begin{array}{c}6-9 \\
\text { months }\end{array}$ & $\begin{array}{c}\text { 9-12 } \\
\text { months }\end{array}$ & $\begin{array}{c}\text { 12-18 } \\
\text { months }\end{array}$ & $\begin{array}{c}\text { 18-24 } \\
\text { months }\end{array}$ & $\begin{array}{c}24 \\
\text { months } \\
\text { or } \\
\text { greater }\end{array}$ & $\begin{array}{l}\text { Row } \\
\text { total }\end{array}$ \\
\hline \multirow{3}{*}{ Aboriginal } & Years 1-3 & 9 & 6 & 3 & 3 & 6 & 0 & 5 & 32 \\
\hline & Years 4-7 & 14 & 8 & 5 & 4 & 3 & 1 & 6 & 41 \\
\hline & Total & 23 & 14 & 8 & 7 & 9 & 1 & 11 & 73 \\
\hline \multirow{3}{*}{$\begin{array}{l}\text { Aboriginal } \\
\text { and Torres } \\
\text { Strait } \\
\text { Islander }\end{array}$} & Years 1-3 & 6 & 5 & 0 & 2 & 5 & 4 & 8 & 30 \\
\hline & Years 4-7 & 10 & 4 & 1 & 1 & 3 & 0 & 6 & 25 \\
\hline & Total & 16 & 9 & 1 & 3 & 8 & 4 & 14 & 55 \\
\hline \multirow{3}{*}{$\begin{array}{l}\text { Torres Strait } \\
\text { Islander }\end{array}$} & Years 1-3 & 8 & 5 & 1 & 1 & 1 & 2 & 3 & 21 \\
\hline & Years 4-7 & 5 & 2 & 3 & 3 & 1 & 3 & 10 & 27 \\
\hline & Total & 13 & 7 & 4 & 4 & 2 & 5 & 13 & 48 \\
\hline \multirow{3}{*}{$\begin{array}{l}\text { Non- } \\
\text { Indigenous }\end{array}$} & Years 1-3 & 14 & 3 & 2 & 3 & 6 & 1 & 6 & 35 \\
\hline & Years 4-7 & 12 & 3 & 2 & 3 & 1 & 2 & 10 & 33 \\
\hline & Total & 26 & 6 & 4 & 6 & 7 & 3 & 16 & 68 \\
\hline
\end{tabular}

As part of the research project, the Mobility Support Teacher and Indigenous Education Worker discussed with each family, the motivations for movement for each enrolling or joining student. The reasons for movement were often complex and entangled as evidenced by the following description of a student's reason for mobility:

"Student, his siblings and mother moved from [community] because of relationship issues. He was enrolled at [another school] while staying with relatives. The family then moved to emergency accommodation and had transport issues” (MST database, 2010).

This student experience exemplifies the difficulty of capturing the reasons for mobility. Nevertheless, the motivations identified by Mobility Support Teachers and Indigenous Education Workers broadly and jointly categorised and are presented in Table 5. Each broad category was informed by a number of sub-categories. For example, 'family circumstances' includes students who had experienced parent relationship changes, changes in custody, or 
were attending to kinship responsibilities such as funerals and birthdays - each of these reasons are listed as detailed reasons for mobility on the data collection tool used by schools.

Table 5: Motivations for mobility for enrolling students in the Greenville Cluster 2010

\begin{tabular}{|c|c|c|c|c|c|c|c|c|c|c|}
\hline \multirow{3}{*}{$\begin{array}{l}\text { Broad motivation for } \\
\text { movement }\end{array}$} & \multicolumn{10}{|c|}{ Enrolling students } \\
\hline & \multicolumn{2}{|c|}{ Aboriginal } & \multicolumn{2}{|c|}{$\begin{array}{l}\text { Torres Strait } \\
\text { Islander }\end{array}$} & \multicolumn{2}{|c|}{$\begin{array}{c}\text { Aboriginal and } \\
\text { Torres Strait } \\
\text { Islander } \\
\end{array}$} & \multicolumn{2}{|c|}{$\begin{array}{c}\text { Non- } \\
\text { Indigenous }\end{array}$} & \multicolumn{2}{|c|}{ All students } \\
\hline & $\#$ & $\%$ & $\#$ & $\%$ & \# & $\%$ & $\#$ & $\%$ & $\#$ & $\%$ \\
\hline Family circumstances & 64 & 67 & 45 & 60 & 29 & 48 & 29 & 37 & 167 & 54 \\
\hline Housing & 15 & 16 & 14 & 19 & 14 & 23 & 13 & 16 & 57 & 18 \\
\hline Seeking services/support & 8 & 8 & 5 & 7 & 6 & 10 & 18 & 23 & 37 & 12 \\
\hline School choice & 4 & 4 & 3 & 4 & 6 & 10 & 3 & 4 & 16 & 5 \\
\hline Employment & 2 & 2 & 3 & 4 & 2 & 3 & 15 & 19 & 22 & 7 \\
\hline Social concerns & 2 & 2 & 1 & 1 & 2 & 3 & 1 & 1 & 6 & 2 \\
\hline Cultural activities & 1 & 1 & 4 & 5 & 1 & 2 & 0 & 0 & 6 & 2 \\
\hline Unknown & 0 & 0 & 0 & 0 & 0 & 0 & 0 & 0 & 0 & 0 \\
\hline
\end{tabular}

As Table 5 shows, a change in family circumstances was the most significant and primary reason for mobility for both Indigenous and non-Indigenous families in Greenville schools. Of the $67 \%$ of Indigenous students enrolling, many had experienced a family breakdown and had moved with one parent. Others were leaving families with domestic violence issues, and others still came from outlying communities to stay with a member of family for a period of time before returning to the community. Those students who were with parents seeking support from domestic violence issues or relationship breakdowns often resided in emergency housing. As such the allowed length of stay at that address was limited. Those students from outlying communities often moved between the community and regional centre, occasionally re-enrolling at the same schools.

The second most significant reason for mobility differed between Indigenous and nonIndigenous families. For Indigenous families, housing concerns prompted or forced movements. For non-Indigenous families, seeking services/ support was the second most significant reason for movement. The latter may be indicative of the increase of refugees enrolling at the schools. For many families in this region, securing permanent housing was an issue so student mobilities represented their journey through the housing system, with some 
experiencing intermittent periods of homelessness. Others were able to organise accommodation with family members. Often; however, these arrangements would " fall through'. These varied reasons are exemplified in the following case note from a Mobility Support Teacher describing the reason for mobility of a student: "Overcrowded housing in [community]. Currently staying in [Community Housing] organised accommodation for three months, then hoping to find permanent residence in the area”. This situation was typical of many families enrolling in the three schools.

\subsection{Direction of movement}

In analysing data regarding the previous schools of enrolling students, the study was also able spatially map provisional patterns of mobility for Indigenous families enrolling in Greenville schools by identifying the most common places of origin. The movement direction of Indigenous students enrolling in the Greenville schools during 2010 is mapped in Fig. 1.

Figure 1: Locational movement of Indigenous students joining Greenville schools in 2010

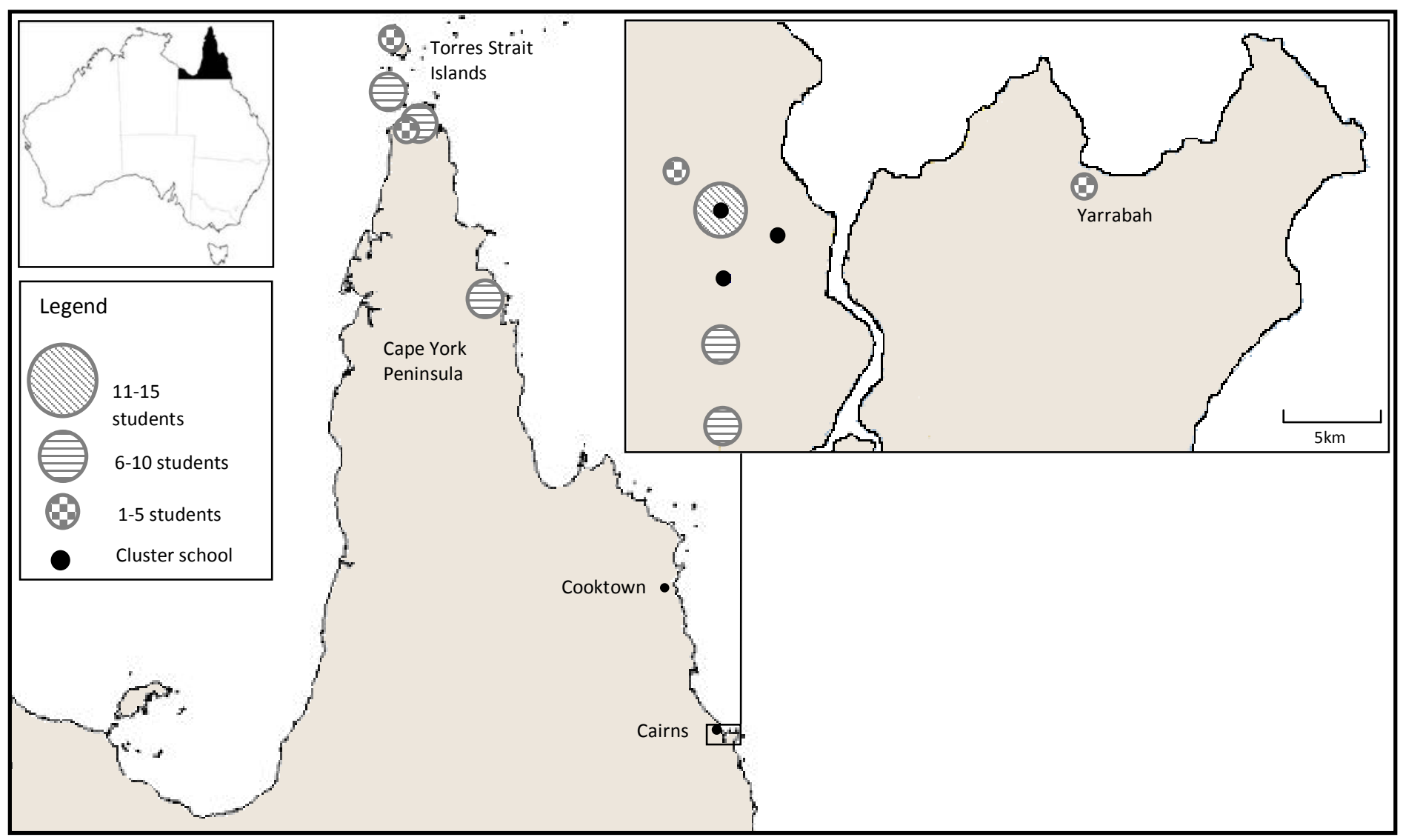


An analysis of the movement direction of Indigenous students reveals two clear patterns of mobility. That is, localised movement and movement from a specific geographical location Cape York and the Torres Strait Islands. For the Greenville schools, 10 schools were commonly noted as the 'previous enrolled' school for 75 Indigenous students (representing $32 \%$ of the joining population). The location of the previous school of joiners revealed that half (52\%) of students were moving less than $20 \mathrm{~km}$ to attend one of the three schools involved in the study - that is, students remained in the Greenville area. This pattern of localised movement may represent the 'churn’ through public housing or emergency accommodation. A small percent of students (5\%) had moved from an Indigenous community, located approximately $50 \mathrm{~km}$ away by road. The remaining joiners (41\%) had relocated from communities in the Cape York Peninsula and Torres Strait Islands, indicating both the historical links with these communities and the need to access services of the major regional centre.

These movements are linked to historical connections to place and accessing regional services. The distance between the Cape York and the Greenville area is approximately 800 $\mathrm{km}$, and access to and from the remote tip of Australia is significantly affected by seasonal weather patterns. Given the history of forced relocation of Indigenous people, many families visit other communities in the Cape York Peninsula area or Cairns area and may become stranded due to road or weather conditions, or financial restrictions. These connections are exemplified in the following Mobility Support Teacher case note:

"Enrolled by grandmother who said he would only be here for three weeks. [Student] and his family came down to [Greenville] for the [Greenville] Show. [Student] is staying in [Greenville] with his grandmother but will be returning to [community] when his uncle's car is repaired” (MST database, 2010).

\section{Cityedge community profile}

In contrast to the profile that demonstrates the preconditions for movement in the Greenville community, Cityedge community profile needs to be first understood for its location at the heart of an urban growth centre of Logan. It is where many young families and migrants move to seek affordable housing and access to employment. Cityedge is located in Australia’s major growth corridor with a rapidly expanding population. The overall population mobility, then, is understandably high with $20 \%$ of the population residing at a 
different address one year previous to the 2006 Australian Census and $44.5 \%$ of the population living at a different address five years previously. The rate of population mobility for Indigenous and non-Indigenous peoples is similar.

As discussed previously, a history of forced relocation has influenced the traditional and historical connections to areas of Indigenous people. Although missions were established near the Cityedge area (one $50 \mathrm{~km}$ north and another $55 \mathrm{~km}$ north- west), the existence of these missions was short-lived. The Cityedge region did not have the same concentration of missions or Indigenous groups as the Greenville region. However, records show that individuals from the two main Indigenous groups that inhabited the area were sometimes relocated considerable distances from their traditional lands, for example, some were relocated to missions approximately $1400 \mathrm{~km}$ north (State Library of Queensland, 2011).

The composition of the population within the Cityedge community is significantly different to the Greenville community, with only $4.2 \%$ identifying as Indigenous - 3.5\% Aboriginal, 0.4\% Torres Strait Islander and 0.3\% both Aboriginal and Torres Strait Islander (OESR, 2008). Similar to the Greenville region, the Indigenous population is very young, with almost half the population aged 14 years or younger (OESR, 2008). The social diversity of the Cityedge community is added to by a large migrant population - one quarter of the population was born overseas and half of those were born in non-English speaking countries (ABS, 2006). The result is an increasing number of people in the Cityedge community speaking a language other than English at home - at the time of the 2006 Australian Census, this represented one quarter of the Cityedge community population (ABS, 2006).

Financial indicators, such as the unemployment rate and rental stress, also contribute to understanding of movement. The unemployment rate for the Cityedge community is significantly higher than the state average, with the Indigenous unemployment rate four times the state average and non-Indigenous unemployment rate double the state average (OESR, 2008). High unemployment rates are reflected in the percentage of dependent children for whom neither parent is employed or in the labour force - 31.8\% for Indigenous and $14.5 \%$ for non-Indigenous couple families (OESR, 2008). Housing tenure in the Cityedge community is similar to the Greenville community, with a rented dwelling the most common type of housing for both Indigenous and non-Indigenous families - 68.7\% and $44.7 \%$ respectively (OESR, 2008). The median weekly rent for Indigenous households with a \$1- 
\$249 gross weekly income was \$206 and such rental stress may be linked to overcrowding in the Cityedge community (OESR, 2008). At the time of the 2006 Australian Census, almost one quarter (22.8\%) of Indigenous households in the Cityedge community were overcrowded (OESR, 2008). With regard to measurements of socio-economic disadvantage, the schools are located in areas that constitute the most disadvantaged communities measurable within Australia - with two schools located in an area with the lowest possible decile of 1 , while the third is in the second lowest decile (ABS, 2006).

\subsection{Profile of schools in Cityedge community}

The school populations range from 500 to 1000 students and include a wide diversity of cultures. There are a range of different cultures represented within the schools, with students from the Pacific nations, African countries such as Burma, Democratic Republic of Congo, Ethiopia, Somalia, Sudan, Sierra Leone, Rwanda and Ghana, Middle Eastern countries such as Iraq and Kuwait as well as South-East Asian locations such as Burma, Laos, Thailand and Cambodia. A large number of students are refugees. A large proportion of students then, have a language background other than English - 17\% at Cityedge East, 34\% at Cityedge North and 59\% at Cityedge South. The proportion of Indigenous students is much smaller than that of the Greenville schools, ranging between $8 \%$ and $11 \%$ across the three schools.

The Index of Community Socio-Educational Advantage (ISCEA) for the schools is slightly higher than the Greenville schools, ranging from 885 to 925. Significantly, approximately $80 \%$ of the student population at each school is located in the bottom two quarters of disadvantage. Therefore, a significant number of families are exposed to a range of issues related to social and economic disadvantage.

\subsection{School mobility in the Cityedge schools}

As with the Greenville schools, administrative data was analysed revealing that, in 2010, 305 students joined and 257 students left the three schools in the Cityedge community. The numbers of students joining and leaving the schools are disaggregated by cultural background as outlined in Table 6 . 
Table 6 Indigenous status of 2010 Joiners and Leavers in the Cityedge cluster

\begin{tabular}{lcc}
\hline Indigenous status & Joiners & Leavers \\
\hline Aboriginal & 34 & 23 \\
Torres Strait Islander & 5 & 4 \\
Aboriginal and Torres Strait Islander & 4 & 5 \\
Non-Indigenous & 262 & 225 \\
\hline
\end{tabular}

Applying the Joiners Plus Leavers (JPL) formula (Dobson et al., 2000), to calculate the Mobility Index for each school, shows that the rate of mobility is less than the Greenville schools but still considered 'high' to 'very high' when benchmarked against international studies. Cityedge East had a Mobility Index of 26.4\%, Cityedge North was calculated as $24.6 \%$ and Cityedge South had the highest level of mobility at $41.7 \%$. Disaggregating the data by Indigenous status, the data indicates the Indigenous population experienced greater mobility than the non-Indigenous population, and that for each school Indigenous mobility would be considered ‘very high’ - Cityedge East 54.4\%, Cityedge East North 34.1\% and Cityedge East $43.4 \%$.

When length of stay data were analysed, a pattern of short stays emerged. The data revealed that almost 40\% of those students who left the Cityedge schools in 2010 stayed for less than 6 months, and of greater significance was that $30 \%$ of all leavers stayed for $0-3$ months. This pattern may be linked to refugee families arriving in Australia and receiving temporary housing in the Cityedge area before finding more permanent housing elsewhere. It is also apparent that short stays (0-6 months) were experienced by $50 \%$ of Indigenous students enrolling in the schools. While the movement of students in Years 1-3 was less than the Greenville schools, it is still significant that $9 \%$ of Indigenous students and $16 \%$ of nonIndigenous students in Years 1-3 remained in the Cityedge schools for less than 6 months or two school terms (Table 7). 
Table 7: Length of Stay for leavers in the Cityedge Cluster 2010 (total number of leavers $=257$ )

\begin{tabular}{|c|c|c|c|c|c|c|c|c|c|}
\hline $\begin{array}{l}\text { Indigenous } \\
\text { Status }\end{array}$ & Cohort & $\begin{array}{c}\text { 0-3 } \\
\text { months }\end{array}$ & $\begin{array}{c}\text { 3-6 } \\
\text { months }\end{array}$ & $\begin{array}{c}6-9 \\
\text { months }\end{array}$ & $\begin{array}{c}9-12 \\
\text { months }\end{array}$ & $\begin{array}{c}\text { 12-18 } \\
\text { months }\end{array}$ & $\begin{array}{c}\text { 18-24 } \\
\text { months }\end{array}$ & $\begin{array}{c}24 \\
\text { months } \\
\text { or } \\
\text { greater }\end{array}$ & $\begin{array}{l}\text { Row } \\
\text { total }\end{array}$ \\
\hline \multirow{3}{*}{ Aboriginal } & Years 1-3 & 2 & 0 & 2 & 0 & 0 & 0 & 2 & 6 \\
\hline & Years 4-7 & 4 & 5 & 2 & 0 & 2 & 1 & 3 & 17 \\
\hline & Total & 6 & 5 & 4 & 0 & 2 & 1 & 5 & 23 \\
\hline \multirow{3}{*}{$\begin{array}{l}\text { Aboriginal } \\
\text { and Torres } \\
\text { Strait } \\
\text { Islander }\end{array}$} & Years 1-3 & 0 & 1 & 0 & 0 & 0 & 1 & 0 & 2 \\
\hline & Years 4-7 & 2 & 0 & 0 & 0 & 0 & 0 & 1 & 3 \\
\hline & Total & 2 & 1 & 0 & 0 & 0 & 1 & 1 & 5 \\
\hline \multirow{3}{*}{$\begin{array}{l}\text { Torres Strait } \\
\text { Islander }\end{array}$} & Years 1-3 & 0 & 0 & 0 & 0 & 0 & 0 & 0 & 0 \\
\hline & Years 4-7 & 2 & 0 & 0 & 0 & 0 & 0 & 2 & 4 \\
\hline & Total & 2 & 0 & 0 & 0 & 0 & 0 & 2 & 4 \\
\hline \multirow{3}{*}{$\begin{array}{l}\text { Non- } \\
\text { Indigenous }\end{array}$} & Years 1-3 & 25 & 12 & 7 & 4 & 22 & 12 & 19 & 101 \\
\hline & Years 4-7 & 35 & 11 & 7 & 6 & 16 & 7 & 42 & 124 \\
\hline & Total & 60 & 23 & 14 & 10 & 38 & 19 & 61 & 225 \\
\hline
\end{tabular}

While in the Greenville schools family circumstances and housing issues were overwhelmingly the most significant reasons for movement for both Indigenous and nonIndigenous peoples, this was not case in the Cityedge schools. Three common reasons for movement emerged. Over half of the students enrolled moved into Cityedge schools due to housing issues or family circumstances, representing $37 \%$ and $22 \%$ of the total joining population respectively. In addition however, seeking services/support was the third reason for movement (21\%). The majority of those seeking services/support were refugees from locations such as Rwanda, Congo, Cambodia and Sudan (Table 8).

Table 8: Motivations for mobility for enrolling students in the Cityedge Cluster 2010

\begin{tabular}{|c|c|c|c|c|c|c|c|c|c|c|}
\hline \multirow{3}{*}{$\begin{array}{l}\text { Broad motivation for } \\
\text { movement }\end{array}$} & \multicolumn{10}{|c|}{ Enrolling students } \\
\hline & \multicolumn{2}{|c|}{ Aboriginal } & \multicolumn{2}{|c|}{$\begin{array}{l}\text { Torres Strait } \\
\text { Islander }\end{array}$} & \multicolumn{2}{|c|}{$\begin{array}{c}\text { Aboriginal and } \\
\text { Torres Strait } \\
\text { Islander }\end{array}$} & \multicolumn{2}{|c|}{$\begin{array}{l}\text { Non- } \\
\text { Indigenous }\end{array}$} & \multicolumn{2}{|c|}{ All students } \\
\hline & $\#$ & $\%$ & \# & $\%$ & \# & $\%$ & \# & $\%$ & $\#$ & $\%$ \\
\hline Family circumstances & 9 & 26 & 1 & 100 & 3 & 75 & 55 & 21 & 68 & 22 \\
\hline Housing & 21 & 60 & 0 & 0 & 0 & 0 & 92 & 34 & 113 & 37 \\
\hline Seeking services/support & 0 & 0 & 0 & 0 & 0 & 0 & 65 & 24 & 65 & 21 \\
\hline School choice & 3 & 9 & 0 & 0 & 1 & 25 & 28 & 10 & 32 & 10 \\
\hline Employment & 1 & 3 & 0 & 0 & 0 & 0 & 22 & 8 & 23 & 7 \\
\hline Social concerns & 1 & 3 & 0 & 0 & 0 & 0 & 6 & 2 & 7 & 2 \\
\hline Cultural activities & 0 & 0 & 0 & 0 & 0 & 0 & 0 & 0 & 0 & 0 \\
\hline Unknown & 0 & 0 & 0 & 0 & 0 & 0 & 0 & 0 & 0 & 0 \\
\hline
\end{tabular}


The reasons for movement for Indigenous families must be interpreted with some caution due to the small numbers of Indigenous students enrolling at each of the schools. For Aboriginal families in the City edge schools, housing issues were the main factor contributing to a move, cited by $60 \%$ of those enrolling. Family circumstances was the second common most reason cited by $26 \%$, followed by school choice influencing $9 \%$ of all moves. For those identifying as both Aboriginal and Torres Strait Islander, family circumstances were the major factors influencing their movement, followed by school choice.

\subsection{Directions of movement}

The spatial patterns of mobility at the Cityedge schools were quite different from those of the Greenville schools, as is expected given the difference in population composition. Within the Cityedge schools the previous school of 121 students (39\% of the joining population) was examined, revealing that almost half (45\%) of students had an overseas location listed as their previous school. This trend is a result of the increase in refugee and migrant families in the area. The second most common pattern of movement was a move of less than $20 \mathrm{~km}$, experienced by $36 \%$ of enrolling students. The final pattern of movement was students who enrolled in one of the Cityedge schools from interstate, this type of movement represented $18 \%$ of the enrolling population. A move of greater than $20 \mathrm{~km}$ but still within state boundaries was not represented within the 11 most common places of origin for enrolling students. Thus there would seem to be three main cohorts within the Cityedge schools forming three patterns of movement - refugee students from overseas, students moving from interstate, and students who move within the Cityedge community.

Although there were small numbers of Indigenous students enrolling in the Cityedge schools, an analysis of previous schools revealed a pattern of localised movement. This movement direction is mapped in Fig. 2. As can be seen, the majority of Indigenous students moved from a school that was in the Cityedge area. 
Figure 2: Locational movement of Indigenous students joining Cityedge schools

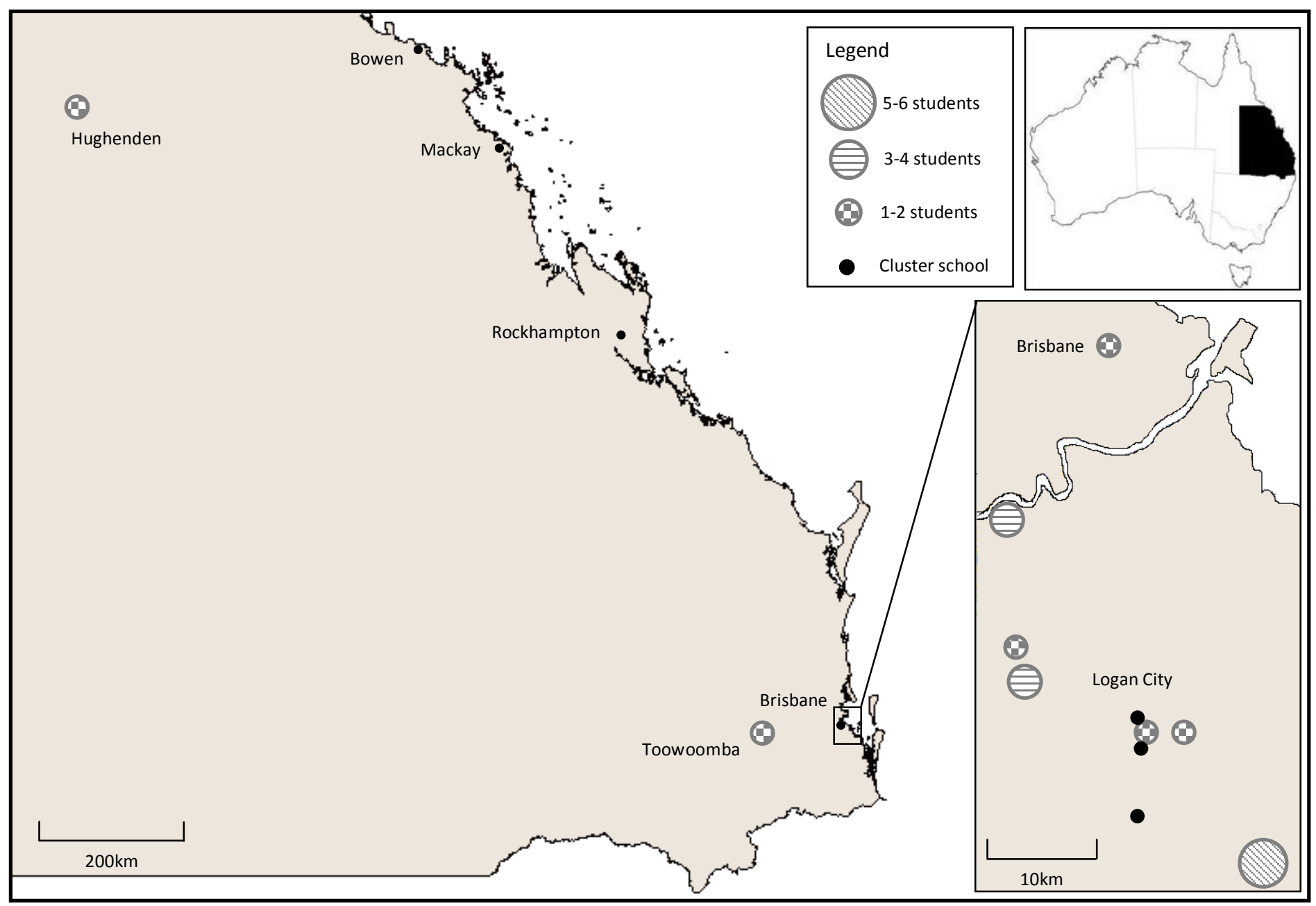

\section{Conclusion}

Paralleling many Indigenous populations around the globe (May \& Aikman, 2003) educational disadvantage remains a key experience of Aboriginal and Torres Strait Islander peoples, located in a history of colonisation, dislocation and racism (Helme, 2007). Australia has moved toward a reconciliation plan with Indigenous peoples, with investment in educational reform to address the ongoing issues of disadvantage. Nevertheless, empirical research that critically examines the ways in which the 'constellation of inequalities' (Darling-Hammond, 2010) can shape schooling and student experiences, provides an important foundation for effective policy responses.

This study highlights that examination of local data sets can reveal particular patterns of mobility. Within both the Greenville and Cityedge schools, localised mobility within the 
Indigenous populations is apparent. In addition, in the Greenville community, particular patterns of spatial mobility may be linked to both the history of the region and the need to access regional services. Family circumstances and housing issues were overwhelmingly the most prominent reason for movement in each area, and while schools may not be able to directly 'stop' this mobility, developing an understanding of mobility enables schools to support students. The short stay patterns of many Indigenous students are particularly in focus when local data sets are carefully examined. The impact of such stays on learning warrants further investigation.

What is clear from the work of schools presented in this paper is that Prout's (2008) call for a more comprehensive and nuanced reading of administrative data in relation to Indigenous mobility is warranted. The high Indigenous mobility rates, the patterns of short stay in one school location, particularly in the early years of schooling, as well as the motivations for movement mapped in this study all suggest some ways forward for policy makers. It is clear from the data in this study, that complex locational factors relating to Indigenous histories and continuing experiences of disadvantage create an intersection with mobility that warrants an investment within a revitalised social inclusion agenda.

\section{Acknowledgements}

We acknowledge the partnership with schools and their communities and between James Cook University, the Department of Education and Training and the Department of Education, Employment and Workplace Relations in the conduct of the research project described in this paper. However, the ideas contained in this paper are those of the authors and do not necessarily represent the views of the funding institution(s), and those who have been acknowledged. 


\section{References}

Appadurai, A. (2000), Grassroots globalization and the research imagination, Public Culture, 12(1): $1-19$

Australian Bureau of Statistics (2006). Basic Community Profile 2006. Retrieved May 30, 2011 from http://www.censusdata.abs.gov.au

Australian Government. Department of Immigration \& Citizenship (2011). Regional Initiatives Retrieved 12 June 2011, from http://www.immi.gov.au/skilled/regionalemployment/

Beesley, A., Moore, L., \& Gopalani, S. (2010). Student mobility in rural and nonrural district in five Central Region states Available from http://ies.ed.gov/ncee/edlabs

Beyer, L. \& Apple, M. (1998). The curriculum: Problems, politics, and possiblities. Albany: State University of New York Press.

Danaher, P., Moriarty, B., \& Danaher, G. (2009). Mobile learning communities. Creating new educational futures. New York: Routledge.

Darling-Hammond, L. (2010). The flat world and education: How America's commitment to equity will determine our future. New York: Teachers College Press.

Department for Education and Skills (2003a). Managing pupil mobility: Guidance. Retrieved September 8, 2006. from

http://www.education.gov.uk/publications/standard/publicationdetail/page1/DfES\%20 $\underline{0780 \% 202003}$

Department for Education and Skills (2003b). Managing pupil mobility: A handbook for induction mentors. Retrieved September 8, 2006. from

http://www.education.gov.uk/publications/standard/publicationdetail/page1/DfES\%20 $\underline{0781 \% 202003}$

Dobson, J., Henthorne, K., \& Lynas, Z. (2000). Pupil mobility in schools: Final report: Migration Research Unit, University College.

Helme, S. (2007). Educational Inequality and Indigenous Australians. In R. Teese, S. Lamb \& Durv-Bellat (Eds.), International Studies in Educational Inequality, Theory and Policy Volume 1: Educational Inequality, Persistence and Change (Vol. 1). New York: Springer.

Lingard, B. (2010). Policy borrowing, policy learning: testing times in Australian schooling. Critical Studies in Education, 51(2), 129-147.

Mantzicopoulos, P., \& Knutson, D. J. (2000). Head Start Children: School Mobility and Achievement in the Early Grades. Journal of Educational Research, 93(5), 305-311.

May, S., \& Aikman, S. (2003). Indigenous Education: Addressing current issues and developments. Comparative Education, 39(2), 139 - 145.

Mellor, S., \& Corrigan, M. (2004). The case for change. A review of contemporary research on Indigenous education outcomes. Camberwell, VIC: Australian Council of Educational Research. 
Office of Economic and Statistical Research (OESR) (2008). Indigenous Regional Profile (Census 2006). Retrieved June 18, 2011 from http://www.oesr.qld.gov.au/index.php

Office for Standards in Education (2002). Managing Pupil Mobility. Retrieved March 12, 2007. from http://www.ofsted.gov.uk/Ofsted-home/Publications-andresearch/Browse-all-by/Education/Leadership/Governance/Managing-pupil-mobility

Prout, S. (2008). On the move? Indigenous temporary mobility practices in Australia, CAEPR Working Paper 48/2008 Available from http://caepr.anu.edu.au/Publications/WP/2008WP48.php

Prout, S. (2009). Policy, practice and the 'revolving classroom door': Examining the relationship between Aboriginal spatiality and the mainstream education system. Australian Journal of Education, 53(1), 39-53.

Prout, S., \& Howitt, R. (2009). Frontier imaginings and subversive Indigenous spatialities. Journal of Rural Studies, 25(4), 396-403.

Queensland Goverment (2011a). Smarter Schools National Partnerships Retrieved 9th June 2011, from http://education.qld.gov.au/nationalpartnerships/

Robertson, S. \& Dale, R. (2011). Expert interview with Editors Susan Robertson and Roger Dale, Co-Editors of Globalisation, Societies \& Education. Retrieved June 9, 2011 from http://www.educationarena.com/expertInterviews/interviewcategory5/cgse.asp

Rumberger, R. (2003). The causes and consequences of student mobility. Journal of Negro Education, 72(1), 6-21.

Sara, C. (2008). The way forward: Indigenous children of the education revolution. Paper presented at the National Press Club. Retrived August 17, 2009 from http://www.abc.net.au/news/opinion/speeches/files/20080526 SARRA.pdf

Smyth, J. (2010). Speaking back to education policy: why social inclusion will not work for disadvantaged Australian schools. Critical Studies in Education, 51(2), 113-128.

Smyth, P. (2008). Social inclusion and place based disadvantage: The Australian context. Fitzroy: The Brotherhood of St Laurence.

State Library of Queensland. (2011). Mainland communities and reserves. Retrieved June 10, 2011 from http://www.slq.qld.gov.au 